\title{
Water Cress in Traditional Medicine of Iran and Modern
}

\author{
Sayed Yahya Kazemi, Seyed Hassan Zali, Azim Naghdizadeh, Sayed Sadegh Mosavi Goloheshmeh, \\ Danyal Tahmasbi Darabi, Abolfazl Fallah
}

\begin{abstract}
These instructions give you guidelines for preparing papers for conferences or journals. Use this document as a template if you are using Microsoft Word. Otherwise, use this document as an instruction set. The electronic file of your paper will be formatted further at FFABS . Define all symbols used in the abstract. Do not cite references in the abstract. Do not delete the blank line immediately above the abstract; it sets the footnote at the bottom of this column. Page margins are $1.78 \mathrm{~cm}$ top and down; $1.65 \mathrm{~cm} \mathrm{left}$ and right. Each column width is $8.89 \mathrm{~cm}$ and the separation between the columns is $0.51 \mathrm{~cm}$.
\end{abstract}

Keywords: Hydrophytes, Water Cress, traditional medicine, Medicinal herbs.

\section{INTRODUCTION}

Water Cress with the scientific name of Nasturtium officinale $\mathrm{R}$. Br. is a species of the family of wallflower or mustard (Brassicaceae). The height of this hydrophyte is 10-60 $\mathrm{cm}$ and its leaves are dark green and its flowers are clustered and white. It has creeping stem from which small white toots come out and it usually grows by streams and swamps. It can be seen in most parts of Iran and its flowering season is from May to July. This plant grows in wild in many parts of Asia and Europe. It has a lot of $\mathrm{Fe}, \mathrm{Ca}$, folic acid, and a little of the vitamins $\mathrm{C}$ and $\mathrm{A}$. The absorbable $\mathrm{Fe}$ in it is more than the $\mathrm{Fe}$ in spinach, then it can be effective to cure anemia. Also its $\mathrm{Ca}$ is more than milk and its vitamin $\mathrm{C}$ is more than orange (1).

\section{MATERIAL AND METHOD}

It is a library study with narrative-review method using traditional medicine books and searching database.

First traditional medicine source were studied and then the modern scientists' findings about medicinal properties and

Sayed Yahya Kazemi, Faculty members, Sari Agricultural Sciences and, Natural Resources University, Iran sykazemi@gmail.com

Seyed Hassan Zali, Faculty members, Sari Agricultural Sciences and Natural Resources University, Iran, hassan.zali@gmail.com

Azim Naghdizadeh, Teacher, Babol General office of Education , Iran azimnaghdi085@gmail.com

Sayed Sadegh Mosavi Goloheshmeh, Student of Aquaculture \& Fishery Sari Agricultural Sciences and Natural Resources University, Iran

Danyal Tahmasbi Darabi, Student of Aquaculture \& Fishery, Sari Agricultural Sciences and Natural Resources University, Iran

Abolfazl Fallah, Student of Aquaculture \& Fishery, Sari Agricultural Sciences and Natural Resources University, Iran main ingredients of water Cress were mentioned.

\section{FINDINGS}

\section{A. Botany:}

Watercress (other names: Kalashak, Bolaq oti, Nasturtium, Garden cress, Water cress)

Botany: It is a plant from Wall flower family with the height of $10-50 \mathrm{~cm}$, little dark green leaves, little clustered flowers, and the little, white roots coming out from creeping stem which grows near streams and swamps (1). It flowering season is from April to July and its usable segment is the leaves (2).

\section{B. The Effective ingredients:}

Studies show that there are Beta-carotene erucic acid, routine fiber, ascorbic acid, Ethyl-phenyl isotiocyanates, alanine, glycine, methionine, niacin, pantothenic acid, gluteus and riboflavin in the leaves and flowers of this plant which causes its anti-cancer property (2). Water cress contains a noticeable $\mathrm{Fe}, \mathrm{Ca}$, folic acid and little vitamins $\mathrm{A}$ and $\mathrm{C}$. The absorbable $\mathrm{Fe}$ of this plant is more than spinach and so it can be used to cure anemia. Also its $\mathrm{Ca}$ is more than the $\mathrm{Ca}$ of milk and its vitamin $\mathrm{C}$ is more than the vitamin $\mathrm{C}$ of orange (1).

\section{Traditional Medicine sources:}

From the ancient times people were familiar with water Cress and attributed various therapeutic properties to it. It was many people's favorite because of its medicinal properties and spicy and savory flavor. Xenophon s the Greek commander and historian told his soldier to eat watercress to strengthen them. Also, in his book about Cyrus the Great he wrote that watercress was one of the main foods of Persians in their training centers. He wrote about the Persian children: "Their main food contains bread and Water cress which they bring from their homes. They have a cup in which they drink water from river." He wrote about teenagers: Teenagers' other food, except what was mentioned, was just the meat of hunted animals or Bolaq oti (water Cress)"(4). The Greeks and AngloSaxons used watercress to cure baldness. Gerard prescribed this plant to treat young girls' white jaundice. Francis Bacon thought it has a magical property to restore the youthfulness of old women. The Irish believed that it was a precious plant which was eaten by wise people. Hippocrates prescribed it as mucus and Diosqurite thought it was diuretic. The raw water Cress or its essence is a strong anti-scurvy. A short-term 
consumption of this plant can cure the side effects of the lack of vitamin C. It is thought that this plant is a blood purifier, strengthener, diuretic, appetizer, stomach tonic, calming the nerve pain, paretic and paraciticide. The mentioned properties as specially applied in common People's medicine. This plant is helpful to treat diabetes and can be used as an expectorant. It can decrease the sugar in diabetic's urine and control eczema and baldness.

\section{Modern Sources:}

A lot of studies show water Cress is an anti-cancer plant. In 2010 a survey in south Hampton University demonstrated that only short while after consuming about $80 \mathrm{gr}$ watercress, the amount of anti-cancer molecules in blood increased and prevented the growth of breast cancer cells, In this way, it prevents the treat cancer growth and recurrence and also it helps to cure the people how suffer this disease (6). A published paper in the journal of "cancer Epidemiology" in 1995 Showed a decrease in the lung cancer progression in smokers by regular daily consumption of $57 \mathrm{gr}$ of water cress (7).

Another survey in Ulster University which was published in "American Journal of clinical Nutrition" in 2007 declared that the daily consumption of 85 gr of this plant during 8 weeks decreases 23 percent of white cells damage caused by cancer. The positive effect of watercress in smokers is more remarkable them others probably it is because of the lack of antioxidants in their bodies (8).

\section{E. Side Effects:}

Since overusing this plant controls cytochrome enzyme of $45 \mathrm{P}$, it may disrupt some medicine metabolisms.

\section{F. Discussion and Results:}

In traditional medicine water Cress has several uses. It can be used as a very sputum, blood purifier, strengthener, diuretic, appetizer, stomach tonic, calming nerve pains, pyretic, paraciticide.

From the effective substances in water Cress we can name Beta-carotene, Erucic acid, fiber routine, ascorbic acid, phenol ethyl phenyl isotiocyanates, Alkyne, Glycine, methionine, Niacin, pantothenic, serine acid, riboflavin and tyrosine (2). However, commenting on the medicinal properties of water Cress needs further laboratory and clinical researches accompanied with effectiveness and safety analysis.

The conclusion of this investigation says that the texts of traditional medicine of Iran have particular instructions and orders about herbal plans such as watercress. By implementing these about herbal plants such as water Cress. By implementing these orders and instructions with modern science and researches on this subject we can be economical in economy, society and emotion.

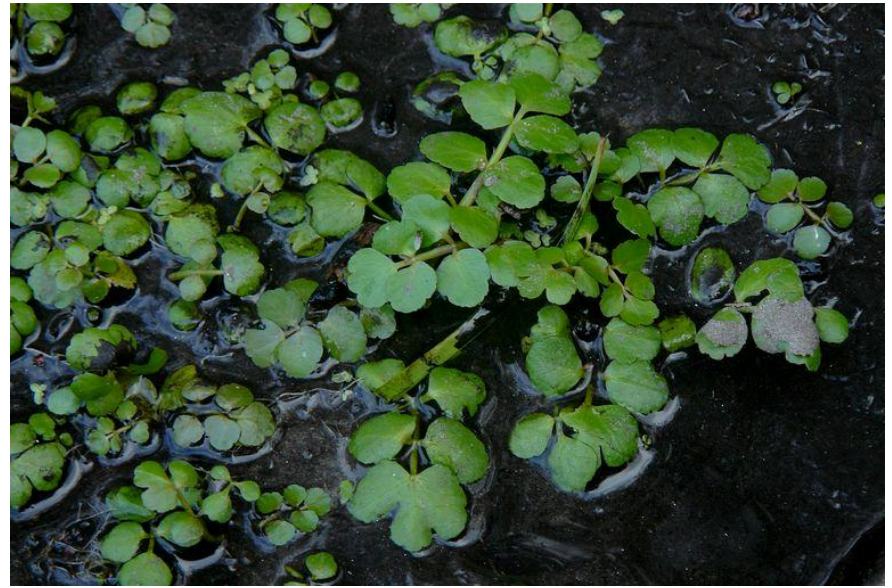

Fig. 1 Water cress

\section{RESOURCES}

[1] Falahatgar Lish, A., 2012. Herb therapy. Nilofaraneh pub. 3rd edition. P. 192.

[2] 2 . Sefidkon, F. Torabi B. Sagvand, M. Naderi and Ghooshegir S.A., 2013. Comparison of anticancer effects of nanocapsules of Nasturtium officinalis (L.) R. Br. extract with methanolic extract and its fractions. Iranian Journal of Medicinal and Aromatic Plants, Vol. 29, No. 1, P. 3550

[3] Mosaheb, G. et al., 2001. Persian Encyclopedia. Amir Kabir Pub.

[4] Pirnia, H., 1991. Ancient Iran History. Doyaeh Ketab Pub. Vol. 1. 5th Edition. P. 247

[5] Davidson, A., Jaine, T., 2006. Watercress. The Oxford companion to food University Press, P. 840.

[6] Richard, G., 2010. Watercress may help fight cancer. Daily Telegraph. http://www.telegraph.co.uk/news/health/news/7957663/Watercressmay-help-fight-cancer.html

[7] Hecht SS, Chung FL, Richie JP, et al., 1995. "Effects of watercress consumption on metabolism of a tobacco-specific lung carcinogen in smokers", Cancer Epidemiology, December 1995 4; 877

[8] Bhat, V., and PA, 2007. Watercress 'helps protect against cancer' Times Online, $15 \quad$ Feb 2007, http://www.thetimes.co.uk/tto/health/article1880546.ece 